\title{
Analisis Kebutuhan Sumber Daya Manusia Terhadap Beban Kerja Di Bagian Rekam Medis Menggunakan Metode (Work Load Indicator Staffing Need) Di Rumah Sakit Umum Permatabunda Medan Tahun 2019
}

\author{
${ }^{1}$ Puput Melati Hutauruk, ${ }^{2}$ Meha Marito Br. Gurning \\ Program Studi D-IV Manajemen Informasi Kesehatan, Universitas Imelda Medan
}

\section{Article Info}

Article history:

Received July 22, 2020

Revised August 29, 2020

Accepted August 30, 2020

Keywords:

Human Resources

Medical Record Unit

WISN

\begin{abstract}
Human Resources (HR) is needed so that the availability of qualified medical personnel and in accordance with the needs of medical personnel needed to ensure the implementation of health development in order to improve the highest degree of public health. The purpose of this research is to know the planning of human resources (HR) needs of the medical record unit at the Medan Permata Bunda Hospital This type of research is descriptive. The method used in this study is the method of observation and interviews. The population in this study was a medical record unit of 9 people. Samples were taken by total sampling. Available working time based on the amount of effective work totaling 2475/year, in 1 effective working day is 7 hours. The number of outpatient visits was 43669 patients/year, while the number of inpatient visits was 9284 patients/year. The standard time allowance for officers is 0.01 minutes. Based on the calculation of workforce requirements using the WISN formula that has been carried out in the medical record unit of the Permata Bunda General Hospital in Medan, there were 13 officers, and the number of officers in the medical record unit was 9 people. It is recommended to Permata Bunda General Hospital to add 4 medical record officers with D3 Medical Record education qualifications.
\end{abstract}

This is an open access article under the CC BY-SAlicense.

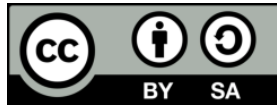

Corresponding Author:

Puput Melati Hutauruk,

Program Studi D-IV Manajemen Informasi Kesehatan,

Universitas Imelda Medan,

Jl. Bilal No. 52 Kelurahan Pulo Brayan Darat I Kecamatan Medan Timur, Medan - Sumatera Utara.

Email: puputmelati.pm71@gmail.com

\section{PENDAHULUAN}

Rumah sakit merupakan pelayanan kesehatan yang sangat strategis dalam upaya mempercepat derajat kesehatan masyarakat. Rumah sakit tidak dapat lagi dikelola dengan manajemen sederhana, tetapi harus mampu memenuhi kebutuhan masyarakat yang muncul akibat berbagai perubahan (Hatta, 2014).

Rumah sakit harus memiliki sumber daya manusia yang profesional baik di bidang teknis maupun pendistribusian, rumah sakit mempunyai tanggung jawab terhadap mutu pelayanan diantaranya adalah rekuitmen terhadap sumber daya manusia yang mempunyai 
kompetensi dan jumlah yang cukup untuk memenuhi kriteria pelayanan kesehatan di rumah sakit.Maka dalam hal ini suatu perencanan Sumber Daya Manusia (SDM) sangat di butuhkan agar tersedianya tenaga medis yang bermutu dan sesuai dengan kebutuhan tenaga medis yang di butuhkan untuk menjamin terselenggaranya pembangunan kesehatan guna meningkatkan derajat kesehatan masyarakat yang setinggi-tingginya (Zebua, 2016).

Berdasarkan PMK Nomor 10 Tahun 2018 tentang pengawasan kesehatan mendefenisikan Tenaga Kesehatan adalah setiap orang yang mengabdikan diri dalam bidang kesehatan serta memiliki pengetahuan dan/atau ketrampilan melalui pendidikan di bidang kesehatan yang untuk jenis tertentu memerlukan kewenangan untuk melakukan upaya kesehatan.

Telah banyak sekali ditemukan penelitian mengenai kebutuhan tenaga rekam medis, yang mana secara tidak langsung sekaligus meneliti tingkat beban kerja tenaga rekam medis di suatu rumah sakit, salah satunya adalah penelitian yang dilakukan oleh penelitian yang dilakukan (Nuryati, 2013) dengan judul Perencanaan Kebutuhan Tenaga Rekam Medis Dengan Metode Workload Indicators Of Staffing Need (WISN). Dipuskesmas Gondokusuman II Kota Yogyakarta menyatakan bahwa tenaga pendaftaran dan rekam medis yang ideal di Puskesmas Gondokusuman II adalah sejumlah 5 orang.

Penelitian yang dilakukan (Bela, 2015) berjudul Tinjauan Perhitungan Beban Kerja Unit Rawat Jalan Pasien BPJS menyatakan bahwa Kebutuhan tenaga yang ada dilapangan belum sesuai dengan beban kerja yang ada yaitu 14,71 jam dengan kebutuhan tenaga 2,34 petugas. Produktivitas petugas kodefikasi dikatakan tidak produktif yaitu 58,57\% jika dihitung berdasarkan standar yang ada guna menunjang produktivitas petugas kodefikasi di rs al-islam bandung.

Penelitian yang dilakukan (Rahmawati, 2015) tentang Analisis Kebutuhan Jumlah Tenaga Kerja Berdasarkan Beban Kerja Di Unit Rekam Medis Rumah Sakit Umum Assalam Gemolong Tahun 2015. Melalui penelitian ini disimpulkan bahwa kebutuhan tenaga rekam medis sebanyak 9 orang, sehingga memerlukan penambahan 1 orang pada bagian filing karena bagian filing masih dirangkap atau dikerjakan oleh petugas pendaftaran dan petugas assembling, coding dan indexing, untuk mencapai produktifitas kerja yang optimal perlu adanya pendayagunaan dan pembagian tugas sesuai dengan job description.

Berdasarkan survei pendahuluan yang dilakukan di RSU Permata Bunda di temukan masalah-masalah yang ada seperti: pertama, Assembling dokumen rekam medis BPJS dilakukan setiap 2 bulan sekali dengan jumlah dokumen yang menumpuk dan dikerjakan oleh petugas lainnya yang bukan bagian assembling. Kedua, terjadinya penumpukan dokumen rekam medis di bagian penyimpanan dikarenakan kekurangan rak. Kurangnya Sumber Daya Manusia secara kuantitas yaitu jumlah tenaga kerja dengan beban kerja tidak sebanding sehingga tenaga kerja merangkap ke beberapa pekerjaan, Hal tersebut menyebabkan tingginya beban kerja yang dirasakan oleh tenaga kerja dan sangat menarik untuk menjadi perhatian.

Berdasarkan permasalahan diatas, penulis tertarik untuk melakukan penelitian dengan judul Analisis Kebutuhan Sumber Daya Manusia Terhadap Beban Kerja Di Bagian Rekam Medis Menggunakan Metode (Work Load Indicator Staffing Need) Di Rumah Sakit Umum Permata Bunda Medan Tahun 2019. Adapun yang menjadi permasalahan adalah bagaimana perencanaan kebutuhan Sumber Daya (SDM) terhadap beban kerja di unitrekam medis menggunakan metode WISN (Workload Indicator Of Staffing Need) di RSU Permata Bunda Medan. 


\section{METODE PENELITIAN}

\section{A. Jenis Penelitian}

Jenis penelitian ini bersifat deskriptif yang bertujuan untuk mengetahui analisis kebutuhan sumber daya manusia terhadap beban kerja di bagian rekam medis menggunakan metode (work load indicator staffing need) di Rumah Sakit Umum Permata Bunda Medan. Penelitian deskriptif adalah penelitian yang tujuannya untuk menjelaskan atau mendeskripsikan suatu peristiwa, keadaan, objek apakah orang atau segala sesuatu yang terkait dengan variabel-variabel yang bisa dijelaskan baik menggunakan angka-angka maupun kata-kata (Setyosari, 2010).

B. Waktu dan Tempat Penelitian

Waktu penelitian dilakukan di RSU Permata Bunda Medan pada bulan Mei tahun 2019.Penelitian ini dilakukan di RSU Permata Bunda Medan yang berlokasi di Jl. Sisingamangaraja No. 7 Medan, Sumatera Utara, Indonesia.

C. Populasi, Sampel, dan Teknik Sampling

Populasi dalam penelitian ini adalah petugas rekam medis sebanyak 9 orang. Sampel merupakan bagian dari jumlah dan karakteristik yang dimiliki oleh populasi tersebut (Sugiyono, 2013). Teknik pengambilan sampel dalam penelitian ini adalah total sampling atau sampling jenuh. Total sampling adalah teknik penentuan sampel apabila semua populasi digunakan sebagai sampel (Sugiyono, 2013).

D. Variabel Penelitian dan Definisi Operasional

Variabel Penelitian adalah sesuatu yang digunakan sebagai ciri, sifat, atau ukuran yang dimiliki atau didapatkan oleh satuan penelitian tentang sesuatu konsep pengertian tertentu (Notoatmodjo, 2010).

Dalam penelitian ini yang menjadi variable penelitiannya adalah:

1. Waktu kerja tersedia

2. Unit kerja

3. Standar beban kerja

4. Standar kelonggaran

5. Kebutuhan petugas rekam medis

Defenisi Operasional

1. Waktu kerja yang tersedia bagi pegawai Unit Pelatihan dan Pengembangan merupakan waktu kerja yang harus dipenuhi oleh pegawai dalam melakukan aktifitas di Rumah Sakit.

2. Unit kerja yang dihitung terkait dengan kuantitas kegiatan pokok dan beban kerja.

3. Standar beban kerja di dapatkan dari waktu kerja yang tersedia yang ada dibagi rata-rata waktu yang digunakan untuk menyelesaikan kegiatan pokok.

4. Standar kelonggaran merupakan waktu yang digunakan untuk melaksanakan kegiatan lain yang tidak berhubungan langsung tetapi bermanfaat bagi pegawai tersebut.

5. Perhitungan jumlah kebutuhan tenaga terkait dengan total kuantitas kegiatan pokok dibagi dengan standar beban kerja.

E. Instrumen dan Cara Pengumpulan Data

Instrumen Penelitian

1. Wawancara

Digunakan untuk mengumpulkan data secara lisan dari seorang sasaran penelitian (responden).

2. Observasi

Digunakan untuk mengamati dalam pelaksanaan tugas di ruangan rekam medis.

3. Stopwatch

Digunakan untuk menghitung lamanay petugas menyelesaikan pekerjaan. 
4. Kalkulator

Digunakan untuk menghitung kebutuhan tenaga rekam medis.

Cara Pengumpulan Data

1. Data primer adalah sumber data yang langsung diperoleh langsung dari subjek peneliti dengan menggunakan alat pengukuran atau alat pengambilan data, yaitu data dari hasil perhitungan waktu dengan menggunakan stopwatch.

2. Data sekunder adalah data yang diperoleh dari hasil wawancara dan observasi yang ada dirumah sakit (Saryono, 2013).

F. Teknik Pengelolahan dan Analisa Data

Teknik Pengolahan Data

1. Editing Merupakan suatu cara pengolahan data yang dilakukan dengan meneliti atau mengoreksi data dan memperbaikinya jika ada kekeliruan pengisian tidak lengkap, sehingga data yang dihasilkan dapat memberikan informasi yang dapat dipertanggung jawabkan sesuai kebutuhan.

2. Tabulasi

Memasukkan dan menyusun hasil penelitian ke dalam bentuk table supaya lebih mudah untuk disajikan nantinya dapat diperoleh gambaran yang jelas mana yang lebih efektif.

3. Entry

Yaitu memasukkan jawaban-jawaban dari responden dalam bentuk kode (angka atau huruf) ke dalam komputer.

Analisis data

Teknik yang digunakan dalam penelitian ini berdasarkan teknik analisis deskriptif yaitu dengan cara mendiskripsikan data yang telah dikumpulkan dan diolah menjadi hasil untuk mengetahui jumlah kebutuhan tenaga kerja dibagian rekam medis di Rumah Sakit Umum Permata Bunda Medan Tahun 2019.

\section{HASIL DAN PEMBAHASAN}

\subsection{Hasil}

Berdasarkan hasil observasi tentang kualifikasi pendidikan petugas rekam medis di RSU Permata Bunda Medan diperoleh data sebagai berikut:

Tabel 1. Kualifikasi Pendidikan Petugas di Unit Rekam Medis

\begin{tabular}{ccc}
\hline \multicolumn{1}{l}{ No } & Nama Petugas & Pendidikan \\
\hline 1. & Petugas A & SMA \\
\hline 2. & Petugas B & SMA \\
\hline 3. & Petugas C & D1 Komputer \\
\hline 4. & Petugas D & S1 Hukum \\
\hline 5. & Petugas E & D3 Perawat \\
\hline 6. & Petugas F & D3 Rekam Medis \\
\hline 7. & Petugas G & D3 Rekam Medis \\
\hline 8. & Petugas H & D3 Rekam Medis \\
\hline 9. & Petugas I & D3 Rekam Medis
\end{tabular}

Sumber : Unit Rekam Medis Rumah Sakit Umum Permata Bunda Medan

Berdasarkan tabel diatas maka data kualifikasi pendidikan dari petugas rekam medis di RSU Permata Bunda Medan yaitu 2 orang SMA, 1 orang D1 Komputer, S1 Hukum, D2 Keperawatan, dan D3 Rekam Medis. 
Perencanaan Kebutuhan SDM Rekam Medis Berdasarkan Beban Kerja di RSU Permata Bunda Medan

Perencanaan kebutuhan SDM unit rekam medis RSU Permata Bunda Medan menggunakan metode Work Load Indicator Staff Need (WISN) sebagai berikut :

\section{Menetapkan Waktu Kerja Tersedia}

Diperoleh dari kerja efektif selama kurun waktu 1 tahun untuk masing-masing kategori SDM yang bekerja di Unit Rekam Medis RSU Permata Bunda Medan dengan jumlah hari kerja tersedia adalah 6 hari. Data yang di dapat sebagai berikut :

Tabel 2. Hari Kerja Tersedia

\begin{tabular}{ccccc}
\hline No & Bulan & Hari & Hari Minggu & Waktu Kerja Tersedia \\
\hline 1 & Januari & 31 & 4 & 27 \\
\hline 2 & Februari & 28 & 4 & 24 \\
\hline 3 & Maret & 31 & 5 & 26 \\
\hline 4 & April & 30 & 4 & 26 \\
\hline 5 & Mei & 31 & 4 & 27 \\
\hline 6 & Juni & 30 & 5 & 25 \\
\hline 7 & Juli & 31 & 4 & 27 \\
\hline 8 & Agustus & 31 & 4 & 25 \\
\hline 9 & September & 30 & 5 & 27 \\
\hline 10 & Oktober & 31 & 4 & 26 \\
\hline 11 & November & 30 & 4 & $\mathbf{3 1 3}$ \\
\hline 12 & Desember & 31 & 5 & Jumlah \\
\hline
\end{tabular}

Sumber : Unit Rekam Medis Rumah Sakit Umum Permata Bunda Medan

Tabel 3. Waktu Kerja Tersedia

\begin{tabular}{clcc}
\hline \multirow{2}{*}{ KODE } & \multirow{2}{*}{ FAKTOR } & KATEGORI & \multirow{2}{*}{ KETERANGAN } \\
\cline { 3 - 4 } & & Unit Rekam Medis & \\
\hline A & Hari Kerja & 313 & Hari/Tahun \\
\hline B & Cuti Tahunan & 12 & Hari/Tahun \\
\hline C & Pendidikan dan Pelatihan & 3 & Hari/Tahun \\
\hline D & Hari Libur Nasional & 19 & Hari/Tahun \\
\hline E & Ketidakhadiran Kerja & 4 & Hari/Tahun \\
\hline F & Waktu Kerja & 9,08 & Jam/Tahun \\
\hline & Waktu Kerja Tersedia & 2497 & Jam/Tahun \\
\cline { 2 - 3 } & A A-(B+C+D+E)*F & 149820 & Menit/Tahun \\
\hline & Hasil Kerja Tersedia & 275 & Hari/Tahun \\
\hline
\end{tabular}

Sumber : Unit Rekam Medis Rumah Sakit Umum Permata Bunda Medan

Uraian perhitungan sebagai berikut :

1. Untuk hari kerja tersedia

Seluruh Kategori SDM : $\{313-(12+3+19+4)\}$

=275 Hari Kerja/Tahun

2. Waktu Kerja Tersedia

Seluruh Kategori SDM : 75 (Hari/Tahun) x 9.08 Jam/Hari

= 2497 Jam Kerja/Tahun 


\section{Menetapkan Unit Kerja Dan Kategori SDM}

Berdasarkan struktur organisasi bagian rekam medis RSU Permata Bunda Medan, membuat perencanaan unit kerja dan kategori bagian rekam medis RSU Permata Bunda Medan yaitu petugas rekam medis berjumlah 9 orang, yang dimana dengan kualifikasi pendidikan SMA 2 orang, 1 orang D1 Komputer, 1 orang D3 Keperawatan, 4 orang D3 Rekam Medis.

\section{Menyusun Standar Beban Kerja}

Standar Beban Kerja yang ada di RSU Permata Bunda Medan di peroleh berdasarkan hasil perencanaan yang dilakukan oleh pihak rumah sakit, karena sistem yang digunakan sudah komputerisasi maka disesuaikan dengan kegiatan yang dilakukan pada saat ini, Standar Beban Kerja yang ada di RSU Permata Bunda Medan adalah sebagi berikut :

Standar beban kerja $=$

Waktu kerja tersedia $\overline{\text { Rata-rata waktu perkegiatan }}$

Tabel 4. Standar Beban Kerja

\begin{tabular}{|c|c|c|c|c|}
\hline No & Kegiatan Pokok & $\begin{array}{c}\text { Rata-Rata } \\
\text { Waktu Kegiatan } \\
\text { (menit) }\end{array}$ & $\begin{array}{c}\text { Waktu Kerja } \\
\text { Tersedia } \\
\text { (menit) }\end{array}$ & $\begin{array}{c}\text { Standar } \\
\text { Beban Kerja } \\
(\text { SBK }) \\
\end{array}$ \\
\hline \multicolumn{5}{|c|}{ Distribusi } \\
\hline 1 & Input tracer & 1,50 & 149820 & 99000 \\
\hline 2 & $\begin{array}{l}\text { Mencari dan mengambil } \\
\text { DRM }\end{array}$ & 5,30 & 149820 & 25781 \\
\hline 3 & $\begin{array}{l}\text { Mendistibusikan DRM ke } \\
\text { poli }\end{array}$ & 8,04 & 149820 & 18470 \\
\hline \multicolumn{5}{|c|}{ Assembling Perusahaan } \\
\hline 1 & $\begin{array}{l}\text { Menerima DRM verifikasi } \\
\text { perusahaan }\end{array}$ & 5,42 & 149820 & 26432 \\
\hline 2 & $\begin{array}{l}\text { Menganalisa kelengkapan } \\
\text { formulir DRM }\end{array}$ & 4,49 & 149820 & 31132 \\
\hline 3 & Merakit DRM & 12,10 & 149820 & 70714 \\
\hline \multicolumn{5}{|c|}{ Assembling Pribadi } \\
\hline 1 & Menerima DRM Kasir & 5,50 & 149820 & 26432 \\
\hline 2 & $\begin{array}{l}\text { Menganalisa kelengkapan } \\
\text { formulir DRM }\end{array}$ & 4,50 & 149820 & 31132 \\
\hline 3. & Merakit DRM & 12,20 & 149820 & 70714 \\
\hline \multicolumn{5}{|c|}{ Assembling BPJS } \\
\hline 1 & $\begin{array}{l}\text { Menerima DRM verifikasi } \\
\text { BPJS }\end{array}$ & 5,34 & 149820 & 26432 \\
\hline 2 & $\begin{array}{l}\text { Menganalisa kelengkapan } \\
\text { formulir DRM }\end{array}$ & 5,00 & 149820 & 31132 \\
\hline 3 & Merakit DRM & 12,10 & 149820 & 70714 \\
\hline \multicolumn{5}{|c|}{ Koding } \\
\hline 1 & $\begin{array}{l}\text { Menerima DRM dari } \\
\text { Assembling }\end{array}$ & 5,12 & 149820 & 29003 \\
\hline 2 & Analisa ketepatan kode & 3,50 & 149820 & 42428 \\
\hline 3 & $\begin{array}{l}\text { Mencari kode penyakit dan } \\
\text { tindakan }\end{array}$ & 5,33 & 149820 & 27861 \\
\hline
\end{tabular}




\begin{tabular}{|c|c|c|c|c|}
\hline 4 & $\begin{array}{l}\text { Menetapkan kode penyakit } \\
\text { dan tindakan }\end{array}$ & 2,10 & 149820 & 70714 \\
\hline 5 & $\begin{array}{l}\text { Menginput ke dalam } \\
\text { computer }\end{array}$ & 2,22 & 149820 & 66891 \\
\hline \multicolumn{5}{|c|}{ Penyimpanan Rawat Inap } \\
\hline 1 & $\begin{array}{l}\text { Menerima DRM dari bagian } \\
\text { Koding }\end{array}$ & 3,44 & 149820 & 43168 \\
\hline 2 & $\begin{array}{l}\text { Menuliskan ke buku } \\
\text { ekspedisi }\end{array}$ & 3.20 & 149820 & 46406 \\
\hline 3 & $\begin{array}{ll}\text { Mengelompokkan } & \text { DRM } \\
\text { berdasarkan bulan } & \end{array}$ & 10,10 & 149820 & 14702 \\
\hline \multicolumn{5}{|c|}{ Penyimpanan Rawat Jalan } \\
\hline 1 & $\begin{array}{l}\text { Petugas mengambil DRM } \\
\text { ke poli / IGD }\end{array}$ & 10,41 & 149820 & 14265 \\
\hline 2 & $\begin{array}{l}\text { Menuliskan ke buku } \\
\text { ekspedisi }\end{array}$ & 3.12 & 149820 & 47596 \\
\hline 3 & $\begin{array}{l}\text { Mengelompokkan } \\
\text { berdasarkan bulan }\end{array}$ & 10,20 & 149820 & 14558 \\
\hline \multicolumn{5}{|c|}{ Pelaporan } \\
\hline \multicolumn{5}{|c|}{ Laporan RL } \\
\hline 1 & $\begin{array}{l}\text { Petugas RM memberikan } \\
\text { data ke setiap ruangan }\end{array}$ & 5.23 & 149820 & 28393 \\
\hline 2 & $\begin{array}{l}\text { Diambil kembali kesetiap } \\
\text { ruangan }\end{array}$ & 5.46 & 149820 & 27197 \\
\hline 3 & $\begin{array}{l}\text { Data di olah dan di input ke } \\
\text { SIRS }\end{array}$ & 10.54 & 149820 & 14089 \\
\hline \multicolumn{5}{|c|}{ Baber Jhonson } \\
\hline 1 & $\begin{array}{l}\text { Menerima data dari bagian } \\
\text { pendaftaran }\end{array}$ & 3,04 & 149820 & 48848 \\
\hline 2 & $\begin{array}{l}\text { Data dioalah oleh petugas } \\
\text { RM }\end{array}$ & 10.40 & 149820 & 14278 \\
\hline \multicolumn{5}{|c|}{ Puskesmas } \\
\hline 1 & $\begin{array}{l}\text { Perawat mengentry data ke } \\
\text { computer }\end{array}$ & 5.03 & 149820 & 29522 \\
\hline 2 & $\begin{array}{l}\text { Petugas menerima dan } \\
\text { mengolah data }\end{array}$ & 10.30 & 149820 & 14417 \\
\hline 3 & Dikirim melalui email & 2.10 & 149820 & 70714 \\
\hline 4 & $\begin{array}{l}\text { Dicetak dan di tanda tangani } \\
\text { oleh direktur RS }\end{array}$ & 6.22 & 149820 & 23874 \\
\hline \multicolumn{5}{|c|}{ Surat DBD } \\
\hline 1 & $\begin{array}{l}\text { Petugas RM menelpon } \\
\text { setiap ruangan }\end{array}$ & 2.50 & 149820 & 59400 \\
\hline 2 & $\begin{array}{l}\text { Petugas RM me ngambil } \\
\text { data ke setiap ruangan }\end{array}$ & 5.10 & 149820 & 29117 \\
\hline 3 & Membuat surat DBD & 10,10 & 149820 & 14702 \\
\hline 4 & $\begin{array}{l}\text { Meminta tanda tangan } \\
\text { direktur }\end{array}$ & 6.22 & 149820 & 23874 \\
\hline
\end{tabular}

Sumber: Unit Rekam Medis RSU Permata Bunda Medan 
Perhitungan sebagai berikut :

Dik : a. Waktu Kerja Tersedia $=149820$ Menit $/$ Tahun

b. Rata-Rata Waktu rawat jalan $=38.57$ Menit

c. Rata-Rata Waktu rawat inap $=2014$ Menit

Dit : Standar Beban Kerja ?

Jwb :Standar Beban Kerja

Rawat jalan $\quad$ Waktu Kerja Tersedia

Rata-rata Waktu

$=\underline{149820}$

38.57

$=3884,3$

Rawat inap $\quad=$ Waktu Kerja Tersedia

Rata-rata Waktu

$=\underline{149820}$

2014

$=7438$

\section{Menyusunan Standar Kelonggaran}

Standar kelonggaran yang ada di RSU Permata Bunda Medan di sesuaikan dengan kegiatan-kegiatan yang ada dan dilakukan oleh masing-masing unit kerja, khususnya untuk unit kerja rekam medis memiliki standar kelonggaran adalah sebagai berikut :

Standar Kelonggaran = Rata-rata waktu faktor kelonggaran

\section{Waktu kerja tersedia}

Tabel 5. Standar Kelonggaran

\begin{tabular}{cccccc}
\hline No & $\begin{array}{c}\text { Nama } \\
\text { Kegiatan }\end{array}$ & $\begin{array}{c}\text { Frekuensi } \\
\text { (Tahun) }\end{array}$ & $\begin{array}{c}\text { Waktu } \\
\text { (Menit) }\end{array}$ & $\begin{array}{c}\text { Total Waktu } \\
\text { Tahun (Menit) }\end{array}$ & $\begin{array}{c}\text { Waktu Kerja } \\
\text { Tersedia (Menit) }\end{array}$ \\
\hline 1 & Rapat Rutin & 24 & 120 & 2880 & 149820 \\
\hline 2 & Pelatihan RM & 3 & 120 & 360 & 149820 \\
\hline
\end{tabular}

Sumber : Unit Rekam Medis RSU Permata Bunda Medan

Rata-rata waktu faktor kelonggaran $=1620$ menit $/$ tahun

Waktu kerja tersedia

$=149820$ menit/tahun

Standar Kelonggaran

= Rata- Rata faktor kelonggaran

$$
=\frac{1620}{149820}
$$

Waktu kerja tersedia

$$
=0,01
$$

\section{Kebutuhan Tenaga Per Unit Kerja}

Tabel 6. Jumlah Pasien Tahun 2018

\begin{tabular}{ccc}
\hline No & Kegiatan Pokok & Frekuensi \\
\hline 1 & Rawat jalan & 43669 \\
\hline & Rawat inap & 9284
\end{tabular}

Sumber :Unit Rekam Medis RSU Permata Bunda Medan

Dalam perhitungan kebutuhan SDM dibutuhkan sumber data yang diperoleh dari langkah-langkah sebelumnya dan kuantitas kegiatan pokok tiap unit kerja selama kurun waktu satu. Data-data yang diperoleh dari langkah-langkah sebelumnya seperti data 
kegiatan pelayanan rawat jalan, rawat inap, standar beban kerja, standar kelonggaran merupakan data untuk perhitungan kebutuhan SDM di setiap unit kerja rekam medis.

Sumber data yang diperlukan untuk menghitung SDM per unit kerja salah satunya adalah Kuantitas Kegiatan Pokok yang di lakukan di unit penyimpanan rekam medis adalah sebagai berikut:

Tabel 7. Kuantitas Kegiatan Pokok

\begin{tabular}{|c|c|c|c|c|}
\hline No & Kegiatan Pokok & $\begin{array}{c}\text { Kuantitas } \\
\text { Kegiatan } \\
\text { Pokok } \\
\end{array}$ & $\begin{array}{c}\text { Standar } \\
\text { Beban Kerja } \\
(\text { SBK }) \\
\end{array}$ & $\begin{array}{c}\text { Kebutuhan } \\
\text { SDM } \\
\text { (Orang) } \\
\end{array}$ \\
\hline \multicolumn{5}{|c|}{ Distribusi } \\
\hline 1 & Input tracer & 43669 & 149820 & 0.45 \\
\hline 2 & Mencari dan mengambil DRM & 43669 & 149820 & 1.56 \\
\hline 3 & Mendistibusikan DRM ke poli & 43669 & 149820 & 2.3 \\
\hline \multicolumn{5}{|c|}{ Assembling Perusahaan } \\
\hline 1 & $\begin{array}{l}\text { Menerima DRM verifikasi } \\
\text { perusahaan }\end{array}$ & 9284 & 149820 & 0.34 \\
\hline 2 & $\begin{array}{l}\text { Menganalisa kelengkapan } \\
\text { formulir DRM }\end{array}$ & 9284 & 149820 & 0.29 \\
\hline 3 & Merakit DRM & 9284 & 149820 & 0.76 \\
\hline \multicolumn{5}{|c|}{ Assembling Pribadi } \\
\hline 1 & Menerima DRM Kasir & 9284 & 149820 & 0.35 \\
\hline 2 & $\begin{array}{l}\text { Menganalisa kelengkapan } \\
\text { formulir DRM }\end{array}$ & 9284 & 149820 & 0.29 \\
\hline 3. & Merakit DRM & 9284 & 149820 & 0.77 \\
\hline \multicolumn{5}{|c|}{ Assembling BPJS } \\
\hline 1 & Menerima DRM verifikasi BPJS & 9284 & 149820 & 0.34 \\
\hline 2 & $\begin{array}{l}\text { Menganalisa kelengkapan } \\
\text { formulir DRM }\end{array}$ & 9284 & 149820 & 0.30 \\
\hline 3 & Merakit DRM & 9284 & 149820 & 0.32 \\
\hline \multicolumn{5}{|c|}{ Koding } \\
\hline 1 & $\begin{array}{l}\text { Menerima DRM dari } \\
\text { Assembling }\end{array}$ & 9284 & 149820 & 0.33 \\
\hline 2 & Analisa ketepatan kode & 9284 & 149820 & 0.22 \\
\hline 3 & $\begin{array}{l}\text { Mencari kode penyakit dan } \\
\text { tindakan }\end{array}$ & 9284 & 149820 & 0.34 \\
\hline 4 & $\begin{array}{l}\text { Menetapkan kode penyakit dan } \\
\text { tindakan }\end{array}$ & 9284 & 149820 & 0.14 \\
\hline 5 & Menginput ke dalam komputer & 9284 & 149820 & 0.14 \\
\hline \multicolumn{5}{|c|}{ Penyimpanan Rawat Inap } \\
\hline 1 & $\begin{array}{l}\text { Menerima DRM dari bagian } \\
\text { Koding }\end{array}$ & 9284 & 149820 & 0.22 \\
\hline 2 & Menuliskan ke buku ekspedisi & 9284 & 149820 & 0.21 \\
\hline 3 & $\begin{array}{ll}\text { Mengelompokkan } & \text { DRM } \\
\text { berdasarkan bulan } & \\
\end{array}$ & 9284 & 149820 & 2.91 \\
\hline \multicolumn{5}{|c|}{ Penyimpanan Rawat Jalan } \\
\hline 1 & $\begin{array}{l}\text { Petugas mengambil DRM ke } \\
\text { poli / IGD }\end{array}$ & 43669 & 149820 & 1.02 \\
\hline 2 & Menuliskan ke buku ekspedisi & 43669 & 149820 & 0.95 \\
\hline 3 & Mengelompokkan DRM & 43669 & 149820 & 2.98 \\
\hline
\end{tabular}




\begin{tabular}{|c|c|c|c|c|}
\hline \multicolumn{5}{|c|}{ berdasarkan bulan } \\
\hline \multicolumn{5}{|c|}{ Pelaporan } \\
\hline \multicolumn{5}{|c|}{ Laporan RL } \\
\hline 1 & $\begin{array}{l}\text { Petugas } \mathrm{RM} \text { memberikan data ke } \\
\text { setiap ruangan }\end{array}$ & 9284 & 149820 & 0.33 \\
\hline 2 & $\begin{array}{l}\text { Diambil kembali kesetiap } \\
\text { ruangan }\end{array}$ & 9284 & 149820 & 0.35 \\
\hline 3 & Data di input ke SIRS & 9284 & 149820 & 0.66 \\
\hline \multicolumn{5}{|c|}{ Baber Jhonson } \\
\hline 1 & $\begin{array}{l}\text { Menerima data dari bagian } \\
\text { pendaftaran }\end{array}$ & 9284 & 149820 & 0.20 \\
\hline 2 & Data dioalah oleh petugas RM & 9284 & 149820 & 0.66 \\
\hline \multicolumn{5}{|c|}{ Puskesmas } \\
\hline 1 & $\begin{array}{l}\text { Perawat mengentry data ke } \\
\text { computer }\end{array}$ & 9284 & 149820 & 0.32 \\
\hline 2 & Petugas menerima data & 9284 & 149820 & 0.65 \\
\hline 3 & Data dioalah & 9284 & 149820 & 0.14 \\
\hline 4 & Dikirim melalui email & 9284 & 149820 & 0.39 \\
\hline 5 & $\begin{array}{l}\text { Dicetak dan di tanda tangani } \\
\text { oleh direktur RS }\end{array}$ & 9284 & 149820 & 0.16 \\
\hline \multicolumn{5}{|c|}{ Surat DBD } \\
\hline 1 & $\begin{array}{l}\text { Petugas menelpon ke setiap } \\
\text { ruangan }\end{array}$ & 9284 & 149820 & 0.16 \\
\hline 2 & Petugas mengambil data & 9284 & 149820 & 0,32 \\
\hline 3 & Pengetikan surat DBD & 9284 & 149820 & 0,64 \\
\hline 4 & Meminta tanda tangan direktur & 9284 & 149820 & 0,39 \\
\hline \multicolumn{4}{|c|}{$\begin{array}{c}\text { SUB SISTEM KEBUTUHAN SDM } \\
\end{array}$} & 11.24 \\
\hline \multicolumn{4}{|c|}{ STANDAR KELONGGARAN } & 0,01 \\
\hline \multicolumn{4}{|c|}{ TOTAL KEBUTUHAN SDM } & 12.48 \\
\hline
\end{tabular}

Berdasarkan rumus yang sudah di tentukan diatas kebutuhan SDM untuk tiap kegiatan pokok terlebih dahulu jumlahkan sebelum ditambahkan dengan standar kelonggaran yang ada di unit rekam medis, dan untuk proses perhitungannya :

Kebutuhan SDM pada bagian rekam medis sebagai berikut :

Sub Total Kebutuhan SDM = Kuantitas Kegiatan Standar Beban Kerja

$$
\begin{aligned}
& =\frac{43669}{3884,3} \\
& =\mathbf{1 1 . 2 4}
\end{aligned}
$$

$=\underline{\text { Kuantitas Kegiatas }}$ Standar Beban Kerja

$=\underline{9284}$

7348

$$
=1.24
$$

Jadi sub total kebutuhan SDM adalah $=11.24+1.24$

$$
\mathbf{= 1 2 . 4 8}
$$


Standar Kelonggaran $=\mathbf{0 . 0 1}$

Jadi, Total Kebutuhan SDM = 12.48+0.01

$$
\begin{aligned}
& =12.49 \\
& =\mathbf{1 3} \text { orang }
\end{aligned}
$$

Jadi jumlah keseluruhan SDM yang di butuhkan di unit rekam medis adalah 13 orang petugas.

\subsection{Pembahasan}

Berdasarkan hasil observasi tentang kualifikasi pendidikan petugas rekam medis di Rumah Sakit Permata Bunda berjumlah 9 orang dan belum seluruhnya berlatar belakang Rekam Medis, 4 diantaranya berpendidikan D3 Rekam Medis, 2 berpendidikan SMA, 1 berpendidikan D1 Komputer, 1 berpendidikan D3 Keperawatan, S1 berpendidikan Hukum. Hal tersebut belum sesuai dengan Permenkes No.55 tahun 2013 yang menyatakan bahwa perekam medis adalah seorang yang telah lulus pendidikan rekam medis dan informasi kesehatan yaitu minimal D3 Rekam Medis sesuai ketentuan peraturan perundang-undang dan telah memiliki STR dan SIK.

Menurut Pasal 77 ayat 1, UU No.13/2003 mewajibkan setiap pengusaha untuk melaksanakan ketentuan jam kerja. Ketentuan jam kerja ini telah diatur dalam 2 sistem seperti yang telas disebutkan diatas yaitu:

1. 7 jam kerja dalam 1 hari atau 40 jam kerja dalam 1 minggu untuk 6 hari kerja dalam 1 minggu; atau

2. 8 jam kerja dalam 1 hari atau 40 jam kerja dalam 1 minggu untuk 5 hari kerja dalam 1 minggu.

Pada kedua sistem jam kerja tersebut juga diberikan batasan jam kerja yaitu 40 (empat puluh) jam dalam 1 (satu) minggu. Apabila melebihi dari ketentuan waktu kerja tersebut, maka waktu kerja biasa dianggap masuk sebagai waktu kerja lembur sehingga pekerja/buruh berhak atas upah lembur.

Waktu kerja petugas rekam medis di RSU Permata Bunda Medan yaitu 9 jam dalam 1 hari dan 48 jam kerja dalam 1 minggu untuk 6 hari kerja. Waktu kerja tersedia berdasarkan jumlah jam kerja efektif di bagian rekam medis berjumlah 2457 jam/tahun, dalam 1 hari jam kerja adalah 9 jam. Berdasarkan dari peraturan diatas jumlah waktu kerja petugas di RSU Permata Bunda Medan belum sesuai dengan ketentuan yang ada.

Adapun hambatan yang terjadi di bagian assembling RSU Permata bunda, dikarenakan dokumen rekam medis rawat inap dengan menggunakan asuransi BPJS diantar ke ruangan rekam medis dalam waktu 2 bulan sekali, sehingga menyebabkan petugas lainnya mengerjakan assembling tersebut. Hambatan berikutnya terjadi di bagian penyimpanan, berkas berserakan dan belum tersusun di rak dikarenakan kurangnya rak penyimpanan dan petugas yang bertugas dibagian penyimpanan juga memiliki tugas dibagian lain di unit rekam medis sehingga menyebabkan terjadinya beban kerja.

Hasil perhitungan secara keseluruhan total kebutuhan sumber daya manusia pada unit Rekam Medis adalah 12.56 atau berjumlah 13 orang petugas sedangkan petugas yang ada di RSU Permata Bunda Medan yaitu berjumlah 9 orang. Sehingga masih perlu adanya penambahan petugas karena belum sesuai dengan standar beban kerja. Dengan adanya penambahan tenaga kerja akan mengurangi beban kerja dan akan dapat meningkatkan pelayanan rumah sakit.

\section{KESIMPULAN}

Berdasarkan penelitian dan perhitungan yang peneliti lakukan maka memperoleh sebuah kesimpulan yaitu :

1. Jumlah dan kualifikasi SDM rekam medis di RSU Permata Bunda medan adalah petugas di unit rekam medis berjumlah 9 orang dengan pendidikan: lulusan D3 RMIK 
sebanyak 4 petugas, D3 Keperawatan 1 petugas, D1 Komputer sebanyak 1 petugas, S1 Hukum sebanyak 1 petugas, SMA sebanyak 2 petugas.

2. Dalam proses pelaksanaannya rekam medis terdapat beberapa hambatan yang dihadapi petugas di bagian assembling RSU Permata bunda, dikarenakan dokumen rekam medis rawat inap dengan menggunakan asuransi BPJS diantar ke ruangan rekam medis dalam waktu 2 bulan sekali, sehingga menyebabkan petugas lainnya mengerjakan assembling tersebut. Hambatan berikutnya terjadi di bagian penyimpanan, berkas berserakan dan belum tersusun di rak dikarenakan kurangnya rak penyimpanan dan petugas yang bertugas dibagian penyimpanan juga memiliki tugas dibagian lain di unit rekam medis sehingga menyebabkan terjadinya beban kerja.

3. Berdasarkan hasil perhitungan kebutuhan petugas rekam medis dengan metode WISN diperoleh hasil keseluruhan adalah 12,56 atau berjumlah 13 orang petugas rekam medis sehingga dibutuhkan penambahan petugas dikarenakan jumlah petugas yang ada berjumlah 9 orang dan diperlukan perbaikan sistem yang ada untuk meningkatkan pelayanan rekam medis.

\section{REFERENCES}

Bela Y. 2015. Tinjauan Perhitungan Beban Kerja Unit Rawat Jalan Pasien BPJS GunaMenunjang Produktivitas Petugas Kodefikasi Di RS Al-Islam Bandung

Departemen Kesehatan Republik Indonesia.2018.Peraturan Menteri Kesehatan RI No. 10 tahun 2018. Pengawasan di Bidang Kesehatan. Jakarta: Departemen Kesehatan RI.

Departemen Kesehatan Republik Indonesia. 2008. Peraturan Menteri Kesehatan RI No. 269 tahun 2008. Rekam Medis. Jakarta: Departemen Kesehatan RI.

Dirjen Yanmed.2006. Pedoman Penyelenggaraan dan Prosedur Rekam Medis Rumah Sakit di Indonesia Revisi II. Jakarta

Eni NR.2015. Analisis Kebutuhan Tenaga Kerja Berdasarkan Beban Kerja Di Unit Rekam Medis Rumah Sakit Umum Assalam Gemolong

Hatta, Gemala.2014. Pedoman Manajemen Informasi Kesehatan Disara Pelayanan Kesehatan. Jakarta : Universitas Indonesia (UI-Press)

Iradat Suryani Zebua. 2016. Analisis Sumber Daya Manusia Terhadap Beban Kerja Di Bagian Penyimpanan Rekam Medis Menggunakan Metode Wisn (Workload Indicator Of Staffing Need) Di Rumah Sakit Umum Pusat H. AdamMalik Medan. [Karya Tulis Ilmiah]. Medan: Akademi Perekam dan Informasi KesehatanImelda.

Keputusan Menteri Kesehatan Republik Indonesia Nomor: 81/Menkes/SK/2004 Tentang Pedoman Penyusunan Perencanaan Sumber Daya Manusia Kesehatan Di Tingkat Profinsi, Kabupaten/Kota Serta Rumah Sakit

Notoatmodjo, Soekidjo. 2010. Metode Penelitian Kesehatan. Jakarta: Rineka Cipta.

Novita Indrawati. 2019. Pengaruh Sumber Daya Manusia, Ketersediaan Infrastruktur, Komitmen Pimpinan, Dan Keteladanan Pimpinan Terhadap Tingkat Maturitas Sistem 
Pengendalian Intern Pemerintah (Studi Pada PemerintahDaerah Kabupaten Indragiri Hulu). Jurnal Akuntansi. 11(1): 43-54.

Nuryati, dkk. 2013. Perencanaan Kebutuhan Tenaga Rekam Medis dengan Metode Workload Indicator Of Staffing Need (WISN) di Puskesmas Gondokusuman II Kota Yogyakarta.

Setyosari, Punaji. 2010. Metode penelitian pendidikan dan pengembangan. Jakarta: kencana.

Sugiyono.2013. Metode Penelitian Kuantitatif, Kualitatif, dan R\&D. Jakarta: Alfabetik.

Undang-undang Republik Indonesia No.13 Tahun 2003 Tentang Ketenaga Kerja, Jakarta. Departemen Kesehatan Republik Indonesia.

\section{BIOGRAPHIES OF AUTHORS}

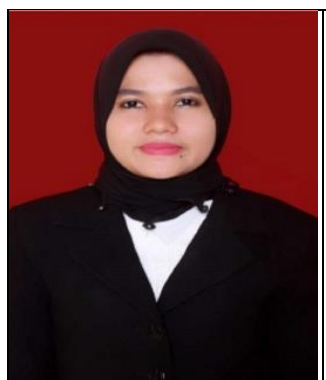

Puput Melati Hutauruk, Gelar Sarjana diperoleh dari Universitas Sari Mutiara Indonesia, Jurusan Administrasi Kebijakan Kesehatan (AKK) pada Tahun 2014. Magister Kesehatan Masyarakat diperoleh dari Universitas Sari Mutiara Indonesia, Jurusan Komite Akreditasi Rumah Sakit (KARS) pada Tahun 2017. Saat ini aktif sebagai pengajar di Program Studi D-IV Manajemen Informasi Kesehatan Universitas Imelda Medan. 